\title{
Effect of Climate Change on Rice
}

\section{Dabi T and Khanna VK*}

School of Crop Improvement, College of Post-Graduate Studies, Central Agricultural University, Barapani, Umiam-793103, Meghalaya, India

\begin{abstract}
Climate change has evolved from a subject of future speculation to an inconvenient reality of the present. Given the inseparable link of agriculture with climatic variables, impact of climate change on agriculture and food security has been at the forefront of the research and policy agenda in recent times. Climatic alteration in India is becoming fairly perceptible, and the changes are far more evident than in other parts of the country. As a result of climate change, extreme abiotic factors like high and low temperatures, droughts, salinity, osmotic stress, heavy rains, floods and frost damages are posing serious threats to rice production and also are detrimental for the farmers earning livelihood from rice cultivation. There is a dire need to frame strategies against these stresses, so that in order to cope with such impacts crop improvement will help in finding the sustainable and effective solution against the negative impact of climate change. Advancement in Molecular breeding will help in utilizing the inherent potential of wild species by generating abiotic tolerant lines through introgression. Large screening of tolerance in wild genotypes should be done with the help of molecular markers to identify the underlying QTLs/genes. With the development in the field of bioinformatics, DNA microarrays, mass spectrometry, RNA-Sequencing or other modern high-throughput genomic techniques, it is now feasible to decipher the underlying metabolic pathways through top down approach. The present paper provides an overview of the recent evidences, potential impacts of climate change on rice and also offers its mitigation strategy through crop improvement with special reference to northeast India.
\end{abstract}

Keywords: Climate change; Rice yield; Abiotic stress mitigation; Molecular breeding

\section{Introduction}

The Earth's climate has changed throughout history. Most of these climate changes are attributed to very small variations in Earth's orbit that change the amount of solar energy our planet receives. Climate change also called global warming refers to an upsurge in average surface temperature on earth which can be revealed by some compelling evidence. According to evidences, seven sister states of North eastern India region are clearly seen affected by climate change which may lead to droughts in the future due to decrease in rainfall and increase in temperature [1]. Although projected rainfall change in the midand late- $21^{\text {st }}$ century is uncertain, increased frequency and severity of extreme climatic events (severe storms, flooding, droughts, etc.) are very likely [2].

\section{Causes of Climate Change}

\section{Natural causes}

The earth's climate is dynamic and always changing through naturally, there are a number of natural factors responsible for climate change. More dominant ones are continental drift, volcanoes, ocean currents, the earth's tilt, comets and meteorites. It has been found from the studies that large explosive volcanic eruptions are a major driving factor of natural climate variability over the past centuries by injecting large amounts of particulate matter (ash) and gases into the stratosphere [3].

\section{Human causes}

Anthropogenic climate change due to industrialization, deforestation, and pollution have greatly increased atmospheric concentrations of water vapor, methane and nitrous oxide which are categorized as greenhouse gases that help to trap heat near earth's surface. Human activities have increased atmospheric carbon dioxide
$\left(\mathrm{CO}_{2}\right)$ concentrations past $400 \mathrm{ppm}$ levels unseen for millions of years [4]. Two broad causes of climate change are shown in Figure 1.

While climate change has the potential to influence the cereal yield directly by heat and water stresses, it can also have an indirect impact by affecting the fertilizer supply, pathogens, and pests [5]. To resolve this problem, the scientific community must find alternative crops that can be adapted and cultivated despite the global warming phenomenon. Simultaneously, these crops should also be able to release less greenhouse gases, must be less resource-intensive, and be rich in major and minor nutrients required for our well-being. Millets are cereal crops that have many of the desirable attributes mentioned above when compared to other major crops [6]. Also, there are several other possible strategies including breeding, technical progress, and improving fertilizer efficiency to increase rice production.

In a world where population size is soaring and reaching unsustainable levels, a drastic reduction in agricultural yields of major cereal crops can significantly hinder ensuring food security. The majority of researchers agree that global warming is irreversible over a short period and requires global policy change and sustainable agricultural practices for a long period to mitigate and reverse the environmental damage.

*Corresponding author: Khanna VK, School of Crop Improvement, College of Post-Graduate Studies, Central Agricultural University, Barapani, Umiam-793103, Meghalaya, India, Tel: 09436997876; E-mail: khannavk@rediff.com

Received August 20, 2018; Accepted October 12, 2018; Published October 22 2018

Citation: Dabi T, Khanna VK (2018) Effect of Climate Change on Rice. Agrotechnology 7:181. doi: 10.4172/2168-9881.1000181

Copyright: (c) 2018 Dabi T, et al. This is an open-access article distributed unde the terms of the Creative Commons Attribution License, which permits unrestricted use, distribution, and reproduction in any medium, provided the original author and source are credited. 




Figure 1: Causes of climate change.

\section{Consequences of Climate Change and its Context to Northeast India}

Global climate change has already had noticeable effects on the environment and such prolonged effects are an alteration of growing season, precipitation patterns, and severe drought and heats waves. Assessment of the impact of climate change can be done based on four important sectors of Indian economy, including water, biodiversity, natural ecosystem and agriculture. We all know the potential of Northeastern states in terms of biodiversity and agriculture, but the area falls under climate sensitive regions of India. This is the reason due to which slight climatic alteration will adversely affect various agricultural activities. The surface air temperature and precipitation of the north eastern region is projected to rise from $1.8^{\circ} \mathrm{C}$ to $2.1^{\circ} \mathrm{C}$ and $0.3-3 \%$, respectively in the 2030s with respect to the 1970s [7]. It will adversely affect the paddy production, tea plantation and other agricultural crop production, which will degrade the overall livelihood of the local people. The main concern is paddy cultivation as rice is the principal food grain crop of the North Eastern hilly ecosystem followed by maize, occupying 3.51 million hectares which accounts for more than $80 \%$ of the total cultivated area of the region and $7.8 \%$ of the total rice area in India while its share in national rice production is only 5.9\% [8].

Before discussing the effects of climate change on paddy, it is important to know about its impact on soil functions. The impact on soils is a sluggish and complex process. It can be strongly affected by climate change; directly and indirectly (Figure 2 ).

Indirectly, the combined impact of climate change is expected to generally increase the yield for some crops. The result of the combined effects of $\mathrm{CO}_{2}$ fertilization, radiation use efficiency and longer growing seasons which mostly complies to plants with the $\mathrm{C}_{3}$ photosynthetic pathway [9] and not prominent to species with the $C_{4}$ pathway [10].

\section{Impact of Climate Change on Rice Yield}

The climate change is going to reduce rice yield in India by $4.5 \%-9 \%$ by 2039 [11]. Global climatic predictions indicated increased frequency of heat spikes and warmer nights, exerting additional challenges towards achieving higher crop yields [12]. The monsoon rainfall is not the only weather variable affecting the kharif rice yield in India [13]. Paddy yield and its response to climate change can be estimated by

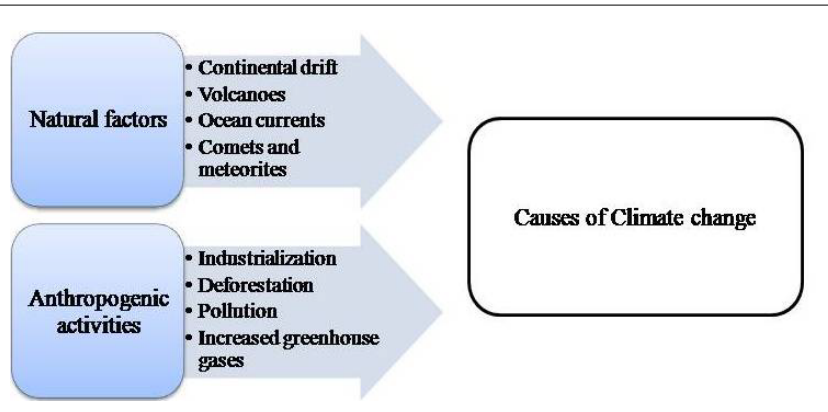

Figure 2: Impact of climate change on soil; direct effects includes loss of $\mathrm{CO}_{2}$ in organic soils, less nutrient availability, erosion, $\mathrm{CH}_{4}$ gas emission, poor soil structure and poor water holding capacity. Crop yield drop and indirect effects include $\mathrm{CO}_{2}$ fertilization, radiation use efficiency of plants, high water use efficiency and increased soil organic matter.

using crop simulation models such as GIS-based environment policy integrated climate (GEPIC) model.

Climatic factors such as temperature, rainfall, atmospheric $\mathrm{CO}_{2}$ and solar radiation are important parameters to rice production [14]. An increase in temperature variability and rainfall variability were found to be beneficial and harmful, respectively to autumn and winter rice yield but these variables were positive as well as insignificant for summer rice [15].

Increasing trend of daily maximum temperature may decrease the rice spikelet fertility, which affects for reduction of the yield while the increasing trend of atmospheric $\mathrm{CO}_{2}$ concentration could increase the rice yield [16]. Temperatures beyond thresholds limit reduces the crop duration of rice and it also results in increased spikelet sterility [17], reduced grain-filling duration [18] and enhanced respiratory rate [19] resulting in lower yield and lower quality rice grain [20]. Rice is highly susceptible to high temperature particularly at flowering stage [17]. The overall effects of multiple climate variables on yield depend on both the sensitivity of yield to the climate variables and the magnitude of change in the climate variables, where temperature and Solar radiation duration plays a crucial role in affecting rice growth and productivity [21].

The rise in night temperature associated with global warming decreases the rice yield. Rice yield tends to be reduced by higher minimum temperature [22] and lower solar radiation [23], especially during the latter part of the growing season. The warming impacts on rice phenology were studied and it was found that climate warming over the past three decades had shortened rice growth period in China [24]. Temperature stress during the flowering period of rice has been experimentally linked to spikelet sterility [25].

The increased level of $\mathrm{CO}_{2}$ from 340 to $680 \mathrm{ppm}$ could increase the yield of major crops by $10 \%-15 \%$ especially in $\mathrm{C}_{3}$ plants like rice $[26,27]$ but the beneficial effects can be negated as the incidence photosynthetically Active Radiation (PAR) is likely to decline by $1 \%$ [28]. A study reported that physiological traits like relative water content (RWC \%), membrane stability index (MSI \%), chlorophyll content, photosynthetic rate and TSS content were improved under elevated $\mathrm{CO}_{2}$ but responses of these traits were negative with elevated temperature [29]. A study showed that panicle initiation period was most sensitive stage to water stress that contributed to a substantial reduction in yield of rice [30]. 


\section{Relationship of Flowering Time of Rice with Photoperiod and Temperature}

The rate of development of rice is generally responsive to photoperiod for only part of their life cycle i.e. between emergence and flowering. Three stages of pre-flowering development can be identified in plants namely the juvenile, inductive, and post-inductive phases. Photoperiod only affects the duration of the inductive phase $[31,32]$. The most important exception is in rice where the duration of the pre-inductive phase also known as the basic vegetative phase or BVP, may exceed 50 days which is quite a long duration [33]. It is of immense importance to quantify and remodel the climate change responses with respect to use of the appropriate temperature driver, not simply the ambient air temperature. A study revealed that it is the temperature nearest to the growing point or meristem that matters [34]. With severe water deficits or at elevated $\mathrm{CO}_{2}$ concentration, large differences between air and tissue temperatures can also arise due to a decrease in cooling effect by transpiration. Hence it is proved that the timing of flowering within a season is largely determined by responses to temperature and photoperiod. To ensure sustained adoption of water-saving technologies under future hotter climates, rice cultivars with enhanced tolerance of combined heat and drought stress during the floral meristem stage will be crucial to complement the progress achieved in overcoming the damage across other sensitive developmental stages such as flowering [35].

\section{Occurrence of Abiotic Stress as a Consequence of Climate Change}

There is an emergence of several abiotic stresses due to the climate change lately. These have negative impact on morphology and physiology of rice plants, hampering its overall growth and development. Some of the adverse conditions are discussed below:

\section{Drought}

The adverse impacts of water shortage on rice crops would be, to a large extent, maintained under elevated ambient $\mathrm{CO}_{2}$ levels, which shows $\mathrm{CO}_{2}$ and drought interactions. According to a study, moisture stress affects rice at morphological (reduced germination, plant height, plant biomass, number of tillers, various root and leaf traits), physiological (reduced photosynthesis, transpiration, stomatal conductance, water use efficiency, relative water content, chlorophyll content, photosystem II activity, membrane stability, carbon isotope discrimination and abscisic acid content), biochemical (accumulation of osmo-protectant like proline, sugars, polyamines and antioxidants) and molecular (altered expression of genes which encode transcription factors and defense related proteins) levels and thereby affects its yield [36]. The reproductive stage is affected by reduced grain formation, inhibited pollen development at meiosis stage and panicle exsertion, which can usually account for $70 \%-75 \%$ spikelet sterility under water stress [37]. It also inhibits processes such as anther dehiscence, pollen shedding, pollen germination, and fertilization [38].

\section{Submergence/flooding}

Rice is semi aquatic in nature and tolerates partial submergence more than any other crops but dies within few days when completely submerged. The flooded environment, created during rice cultivation, provides anaerobic conditions that favor $\mathrm{CH}_{4}$ production by methanogens [39]. A study concluded that anaerobic conditions affect glycolysis promoting ethanol and lactate production through ethanolic fermentation pathway [40]. In a study, it is mentioned about the toxicity of ethanol since it can diffuse out of the cell and results in the formation of acetaldehyde as a toxic intermediate [41]. It was concluded from the study that varieties and submergence duration had significant influence on morphological characters of rice at early vegetative stage [42].

\section{Chilling stress}

Low temperature is a major factor limiting rice growth and yield, and seedling is one of the developmental stages at which sensitivity to chilling stress is higher [43]. Chilling stress triggers a series of changes in physiological and molecular processes and, results in the accumulation of reactive oxygen species (ROS) in plant cells [44]. Indica types are generally sensitive to cold as compared with japonica.

\section{Saline soils and coastal salinity}

Nearly 6.7 million ha of rice growing region are affected by salinity stress in India, or $15.76 \%$ of their total harvested area which is a result of climate change [45]. In a report from a study it was found out that salt-stress damage could be heightened by the interactions between high temperature and relative humidity (vapor pressure deficit-VPD) [46]. Rice can be categorized as moderately salt sensitive crop and under high-salinity conditions, photosynthesis, protein synthesis and metabolism are significantly affected. Under salinity stress, the accumulation of reactive oxygen species (ROS) including superoxide radicals, $\mathrm{H}_{2} \mathrm{O}_{2}$, and hydroxyl radicals has been termed as an important cause of damage to the plant cell [47].

\section{Acidic soil}

Soil $\mathrm{pH}$ levels range from 0 to 14 , with 7 being neutral. Levels below 7 are acidic, and those above are alkaline. Acid soils significantly limit crop production worldwide because approximately $50 \%$ of the world's potentially arable soils are acidic. The primary limitations on acid soils are toxic levels of aluminum ( $\mathrm{Al})$, manganese $(\mathrm{Mn})$ and iron $(\mathrm{Fe})$ as well as suboptimal levels of phosphorous (P) [48]. The main reason of soil acidity in high rainfall areas such as North East India is due to high rainfall and soil erosion.

\section{Approaches to Mitigate Abiotic Stress through Crop Improvement and its Achievements}

There are several options to counter abiotic stress generated by climate change. Crop improvement approach is one of the most effective ways to deal with abiotic stress. Numerous works have been done to counter the impact of climate change in rice. Climate robust rice system should be designed to cope with increased risk of abiotic stress. The concepts of climate resilient agriculture have been of immense importance recently. It enhances the resilience of Indian agriculture to climate change and climate variability through strategic research and technology demonstration. Different activities are performed by diverse branches of agriculture and its integration to increase the resilience against climate change. Crop improvement will help in finding the sustainable and effective solution against the negative impact of climate change.

Crop improvement helps in developing high-temperature tolerant cultivars. According to the modulation of crop growing period, early or late maturing cultivars should be adopted. Also, the crop models have been used to estimate crop yield potential at scales ranging from a specific field to a region or country [49]. Thus crop growth simulation models can replace the need for years of costly multi location, on station and on farm trials to select rice varieties. In context to plant breeding, technical advancement in the field of molecular markers 
led to the development of new branch called "molecular breeding". Conventional plant breeding such as selection, introduction, pureline, pedigree method, backcrossing, intercrossing, single seed descent and topcross can also be used. Developing a variety tolerant to abiotic stress is very tedious and complex work. The mechanism underlying abiotic stress tolerance in plants is not well understood. Many previous 'omics' studies, which can reveal highly informative expression patterns of genes/proteins that reflect the differentiation of response among genotypes with contrasting stress tolerance, have been performed to unravel the abiotic stress-responsive mechanisms in plants [50-52]. Disclosure of new approach is gaining popularity among the molecular biologist, it is known as top-down approach which involves metabolic network reconstructions using 'omics' data (e.g., transcriptomics, proteomics) generated through DNA microarrays, RNA-Seq or other modern high-throughput genomic techniques using appropriate statistical and bioinformatics methodologies [53].

Yield under drought is a function of yield potential, escape and drought response. The use of the Drought Resistance Index (DRI) can help to distinguish drought resistance from escape and yield potential [54]. Therefore, yield under drought can be evaluated to screen drought tolerance rice genotypes. Quantitative trait loci (QTLs) related to drought resistance is identified with the help of QTL mapping. The regions of chromosome responsible for drought tolerance are tagged with the help of molecular markers. The variety Sahbhagi Dhan, released and notified in India in 2010, showed a consistently good performance under rain-fed direct seeded upland and transplanted low land conditions [55]. A variety named Vandana tolerant to drought has been developed by Marker Assisted Selection (MAS) (Figure 3) [56]. New drought-resistant rice varieties such as RD12 for glutinous and RD33 for non-glutinous rice are also being produced with the application of DNA technology. Oryza glaberrima, a wild species of rice is a useful genetic source since it has a habit of early-morning flowering and high transpiration with sufficient water both of which are convenient traits for avoiding heat stress [57]. Rice proteome represents a phenomenal source of proteins that govern traits of agronomic importance, such as

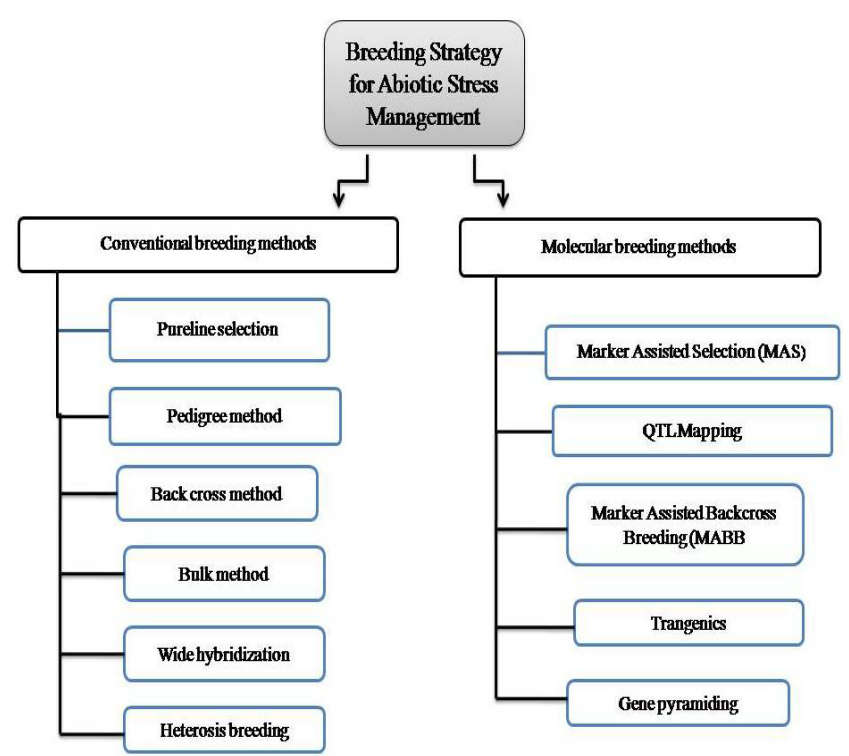

Figure 3: Strategy for abiotic stress management. Conventional methods includes Pureline Selection, Pedigree Method, Backcross method, Bulk, Wide hybridization, Heterosis breeding. Advanced method includes MAS, QTL mapping, MABB, Transgenics, Gene pyramiding. drought tolerance. A comparison study of root cytoplasmic proteome was done for a drought tolerant rice cultivar in PEG induced drought conditions and the largest percentage of identified proteins was found to be involved in bioenergy and metabolism (29\%) and mainly consists of malate dehydrogenase, succinyl-CoA, putative acetyl-CoA synthetase and pyruvate dehydrogenase, etc. which showed a large contribution toward drought regulatory mechanism in rice [58].

Internode elongation is the simplest mechanism of the submergence tolerance in deep rice. The most widely used variety is FR13A, a tall, photoperiod-sensitive variety of the aus-type rice from India [59]. Unraveling the genetic basis of the submergence tolerance is necessary. Ample number of genetic studies [60,61] have suggested that $~ 70 \%$ of the phenotypic variation that results in submergence tolerance of the rice genotypes is contributed by a major QTL [Submergence1 (Sub1)] located on rice chromosome 9 [62]. Three ethylene-responsive transcription factor (ERF) genes (SUB1A, SUB1B, and SUB1C) have been identified, out of which the SUB1A-1 allele has been identified as the major determinant of tolerance [63]. Varieties such as Swarna-sub-1, Samba mahsuri-sub 1, IR64-sub-1, etc. showing submergence tolerance were developed by using Marker Assisted Backcross Breeding (MABB) (Table 1). A transcriptomic comparison between deepwater rice and non-deepwater rice during submergence revealed that the expression of genes related to gibberellin biosynthesis, trehalose biosynthesis, anaerobic fermentation, cell wall modification and transcription factors that include ethylene-responsive factors was significantly different between the varieties, and also suggested the role of jasmonic acid in the submergence response of rice [64]. A study validated the transcriptome data through q-PCR of selected genes and biochemical analysis related to carbohydrate metabolism, anaerobic respiration and oxidative stress tolerance were found more significant in submergence tolerant genotype when compared to susceptible one [65].

Rice growing states such as West Bengal and Orissa have a large share of coastal areas that suffer from salinity. A major QTL, Saltol responsible for salinity tolerance was identified on chromosome 1 of

\begin{tabular}{|c|c|c|c|c|c|}
\hline $\begin{array}{c}\text { Variety } \\
\text { developed }\end{array}$ & $\begin{array}{c}\text { Method of } \\
\text { development }\end{array}$ & $\begin{array}{c}\text { Abiotic } \\
\text { stress } \\
\text { tolerance }\end{array}$ & $\begin{array}{c}\text { Gene/ } \\
\text { QTL }\end{array}$ & Parent/Donor & Reference \\
\hline $\begin{array}{l}\text { Swarna- } \\
\text { sub-1 }\end{array}$ & MABB & $\begin{array}{l}\text { flash flood } \\
\text { tolerance }\end{array}$ & $\begin{array}{l}\text { Sub } 1 \\
\text { gene }\end{array}$ & $\begin{array}{l}\text { O. sativa ssp. } \\
\text { indica cultivar } \\
\text { FR13A }\end{array}$ & [79] \\
\hline $\begin{array}{l}\text { Samba } \\
\text { Mahsuri- } \\
\text { sub } 1\end{array}$ & MABB & $\begin{array}{l}\text { flash flood } \\
\text { tolerance }\end{array}$ & $\begin{array}{l}\text { Sub } 1 \\
\text { gene }\end{array}$ & $\begin{array}{c}\text { FR13A } \\
(\text { IR49830) }\end{array}$ & {$[80]$} \\
\hline $\begin{array}{l}\text { IR } 64- \\
\text { sub-1 }\end{array}$ & MABB & $\begin{array}{c}\text { flash flood } \\
\text { tolerance }\end{array}$ & $\begin{array}{l}\text { Sub } 1 \\
\text { gene }\end{array}$ & FR13A & {$[80]$} \\
\hline $\begin{array}{l}\text { CR 1009- } \\
\text { sub } 1\end{array}$ & MABB & $\begin{array}{l}\text { flash flood } \\
\text { tolerance }\end{array}$ & $\begin{array}{l}\text { Sub } 1 \\
\text { gene }\end{array}$ & FR13A & {$[80]$} \\
\hline $\begin{array}{l}\text { Sahbhagi } \\
\text { Dhan }\end{array}$ & Hybridization & $\begin{array}{c}\text { drought } \\
\text { tolerance }\end{array}$ & - & $\begin{array}{l}\text { IR55419-04 X } \\
\text { Way Rarem }\end{array}$ & [81] \\
\hline Vandana & MAS & $\begin{array}{c}\text { drought } \\
\text { tolerance }\end{array}$ & $\begin{array}{l}\text { qtl.12.1, } \\
\text { qtl3.1, } \\
\text { qtl1.1, } \\
\text { qtl9.1. }\end{array}$ & Way Rarem & [82] \\
\hline $\begin{array}{l}\text { CSR } 43 \text {, } \\
\text { CSR } 10, \\
\text { CSR } 36\end{array}$ & Selection & $\begin{array}{c}\text { Sodic soil } \\
\text { tolerant }\end{array}$ & - & $\begin{array}{c}\text { KDML105/ } \\
\text { IR4630-22-2-5- } \\
\text { 1-3/ IR 20925- } \\
\text { 33-3-1-28 }\end{array}$ & [83-85] \\
\hline $\begin{array}{l}\text { Improved } \\
\text { Pusa } \\
\text { Basmati } \\
1121\end{array}$ & $\begin{array}{l}\text { MABB and } \\
\text { MAS }\end{array}$ & $\begin{array}{c}\text { Saline soil } \\
\text { tolerant }\end{array}$ & $\begin{array}{l}\text { Saltol } \\
\text { (QTL) }\end{array}$ & $\begin{array}{l}\text { Pokkali X IR } 29 \\
\text { FL478 (RIL), } \\
\text { Nona Bokra }\end{array}$ & [86] \\
\hline
\end{tabular}

Table 1: Achievements in the field of abiotic stress management. 
Pokkali, and SKC1 (OsHKT1;5). A gene located within the Saltol region was also identified from Nona Bokra [66]. Breeders are trying to combine SUB1 gene and Saltol in the same type of rice through gene pyramiding, increasing the rice plant's tolerance to salinity and submergence [67]. In a study for salinity stress tolerance, quantitative proteome analysis revealed that total of 56 proteins were significantly altered and 16 of them were enriched in the pathways of photosynthesis, antioxidant and oxidative phosphorylation [50]. A study concluded that identification of root hair-preferential genes and in depth analysis of those genes will be a useful reference to accelerate the understanding of root-hair development in rice [68]. Deciphering the underlying miRNAs-based mechanisms for streamlining nutrient uptake and transport would be a giant step towards solving this puzzle [69].

Molecular genetic tools have been urgently sought to improve rice chilling tolerance in order to maintain rice production in current regions and expand it into northern areas with lower yearly temperatures. It was found that overexpression of COLD1jap significantly enhances chilling tolerance, whereas rice lines with deficiency or down regulation $\mathrm{p} / \mathrm{of}$ COLD1jap are sensitive to cold [70]. OsCTZFP8 is a $\mathrm{C}_{2} \mathrm{H}_{2}$ zinc finger transcription factor that plays an important role in cold tolerance in rice [71]. Multi-locus probability tests and linkage disequilibrium (LD) analyses detected 46 functional genetic units (FGUs) (37 single loci and 9 association groups or AGs) distributed in 37 bins ( 20\%) across the rice genome for Cold Tolerance [72].

Acid soils have aggravated levels of $\mathrm{Al}, \mathrm{Mn}$ and $\mathrm{Fe}$ as well as low levels of phosphorous $(\mathrm{P})$. The source of $\mathrm{P}$ has become limited in upland soil by P-fixation as acidic nature of soil and removal of more $\mathrm{P}$ from lowland conditions [73]. 10 QTL for Al tolerance in rice using a double haploid population were detected and also three QTL were identified by using recombinant inbred lines derived from a cross between one cultivar and one wild species [74]. Elevated $\mathrm{CO}_{2}$ concentration that counters $\mathrm{Al}$ toxicity by decreasing cell wall hemicellulose in rice was reported [24]. Phosphorus uptake1 (PUP1), a major quantitative trait locus derived from Kasalath is reported to exhibit $78.8 \%$ phenotypic variance for P-uptake and the only available QTLs for marker assisted selection in rice [75]. A major candidate gene OsPSTOL1 (Phosphorus starvation tolerance 1) in the PUP1 QTL has been cloned and gene based markers are available for maker assisted gene pyramiding in the different genetic background of rice [76]. Analysis of transcriptome data helped to identify differentially expressed genes associated with phosphate starvation on a genome scale and confirmed the metaexpression patterns of two genes stimulated by $\mathrm{Pi}$ starvation, which suggested novel promoters for enhancing Pi (inorganic Phosphorus) use efficiency [77]. Genetic variation in adaptation and tolerance for iron toxicity has been utilized for the development of iron toxic tolerant cultivars. There is a need to exploit genetic variability available among the different accessions. Recently, a unique QTL, qFRSDW11 associated with Iron and zinc toxicity tolerance was identified [78]. Therefore, pyramiding of genes/QTLs from different sources could result in higher level of tolerance in new varieties.

\section{Conclusion}

Genus Oryza consists of 24 species, out of which O. sativa and $O$. glabberima are known for cultivation. All the remaining 22 species are wild in nature and act as a reservoir of several abiotic tolerance genes; large screening of tolerance in wild genotypes should be done with the help of molecular markers to identify the underlying QTLs/ genes. Molecular breeding will help in utilizing the inherent potential of wild species by generating abiotic tolerant lines through introgression. Genome sequencing of other Oryza genome types which have not been sequenced can hasten the approach of developing abiotic stress tolerant variety. Transcription factors C-repeat/dehydration-responsive element binding proteins (CBF/DREBs) are known regulators of abiotic stress responses [79-87]. Transcriptomics and proteomics study of these proteins in wild genotypes, together with the available and newly generated QTL map will be key to counter the impact of climate change.

\section{References}

1. Mondal A, Khare D, Kundu S (2014) Spatial and temporal analysis of rainfall and temperature trend of India. Theor Appl Climatol 122: 143-158.

2. Africa Agriculture Status Report (2014): Climate change and smallholder agriculture in sub-Saharan Africa. Nairobi, Kenya.

3. Jungclaus JH, Lorenz SJ, Timmreck C, Reick CH, Brovkin V, et al. (2010) Climate and carbon-cycle variability over the last millennium. CP 6: 723-737.

4. Biello D (2015) Accelerated innovation is the ultimate solution to climate change. Scientific American.

5. Porter JR, Xie L, Challinor AJ, Cochrane K, Howden SM, et al. (2014) Food security and food production systems. Climate change 2014: impacts, adaptation, and vulnerability. Part A: global and sectoral aspects 7: 485-533.

6. Jain N, Arora P, Tomer R, Mishra SV, Bhatia A, et al. (2016) Greenhouse gases emission from soils under major crops in Northwest India. Sci Total Environ 542: 551-561.

7. Lalzarliana C (2016) Sustainable agriculture development through expansion, enhancement and modelling in the state of Mizoram. National adaptation fund for climate change (NAFCC), Dept. of Agriculture, Mizoram1-56.

8. Ngachan SV, Mohanty AK, Pattanayak A (2011) Status paper on rice in North East India. ICAR Research Complex for NEH Region, (RKMP) Directorate of Rice Research 1-82.

9. Pathak H, Aggarwal PK, Singh SD (2012) Climate change impact, adaptation and mitigation in agriculture: Methodology for assessment and application. CCAFS 1-302.

10. Allen NJ, Meyer JP (1996) Affective, continuance, and normative commitment to the organization: An examination of construct validity. J Vocat Behav 49: 252-276.

11. Guiteras R (2009) The impact of climate change on Indian agriculture University of Maryland, Maryland 1-54.

12. IPCC (2013) Working Group I contribution to the IPCC fifth assessment report on climate change 2013: The Physical Science Basis, Summary for Policymakers 1-28.

13. Cruz RV, Harasawa H, Lal M, Wu S, Anokhin Y, et al. (2007) Asia. Climate Change 2007: Working Group II: Impacts, adaptation and vulnerability 7: 469 506 .

14. Nyang'au WO, Mati BM, Kalamwa K, Wanjogu RK, Kiplagat LK (2014) Estimating rice yield under changing weather conditions in Kenya using CERES rice model. IJA 2014 2: 1-12.

15. Nath HK, Raju M (2018) Heterogeneous climatic impacts on agricultura production: Evidence from rice yield in Assam, India. AJAD 15: 23-42.

16. Dharmarathna WR, Weerakoon SB, Rathnayaka UR, Herath S (2012) Variation of Irrigated rice yield under the climate change scenarios. InSAITM research symposium on Engineering Advancements 31-34.

17. Jagadish SV, Craufurd PQ, Wheeler TR (2008) Phenotyping parents of mapping populations of rice for heat tolerance during anthesis. Crop Sci 48: 1140-1146.

18. Kim J, Shon J, Lee CK, Yang W, Yoon Y, et al. (2011) Relationship between grain filling duration and leaf senescence of temperate rice under high temperature. Field Crop Res 122: 207-213.

19. Mohammed AR, Tarpley $L$ (2009) Impact of high nighttime temperature on respiration, membrane stability, antioxidant capacity, and yield of rice plants. Crop Sci 49: 313-322.

20. Fitzgerald MA, Resurreccion AP (2009) Maintaining the yield of edible rice in a warming world. FPB 36: 1037-1045.

21. Tao F, Zhang S, Zhang Z (2012) Spatiotemporal changes of wheat phenology in China under the effects of temperature, day length and cultivar therma 
characteristics. Eur J Agron 43: 201-212.

22. Wassmann R, Hirano T, Miyata A, Kumar A, Padre A, et al. (2009). $\mathrm{CO}_{2} /$ heat fluxes in rice fields: Comparative assessment of flooded and non-flooded fields in the Philippines. Agr Forest Meteorol 149: 1737-1750.

23. Peng S, Huang J, Sheehy JE, Laza RC, Visperas RM, et al. (2004) Rice yields decline with higher night temperature from global warming. P Natl Acad Sci Usa 101: 9971-9975

24. Zhang T, Huang Y, Yang X (2013) Climate warming over the past three decades has shortened rice growth duration in China and cultivar shifts have further accelerated the process for late rice. Glob chang biol 19: 563-570.

25. Nakagawa T, Kitagawa H, Yasuda Y, Tarasov PE, Nishida K (2003) Asynchronous climate changes in the North Atlantic and Japan during the last termination. Science 299: 688-691.

26. Allen LH (1990) Plant responses to rising carbon dioxide and potentia interactions with air pollutants. J Environ Qual 19:15-34.

27. Cure JD, Acock B (1986) Crop responses to carbon dioxide doubling: A literature survey. Agr Forest Meteorol 38:127-45.

28. Hume CJ, Cattle H (1990) The greenhouse effect meteorological mechanisms and models. Outlook on Agriculture 19: 17-23.

29. Dwivedi SK, Kumar S, Prakash V, Mondal S, Mishra JS (2015) Influence of rising atmospheric $\mathrm{CO}_{2}$ concentrations and temperature on morphophysiological traits and yield of rice genotypes in sub humid climate of Eastern India. AJPS 6: 2239

30. Zaman NK, Abdullah MY, Othman S, Zaman NK (2018) Growth and physiological performance of aerobic and lowland rice as affected by water stress at selected growth stages. Rice Sci 25: 82-93.

31. Roberts EH, Summerfield RJ, Atherton JG (1987) Manipulation of flowering: Proceedings of previous easter schools in agricultural science. Ed:17.

32. Yin X, Kropff MJ, Horie T, Nakagawa H, Centeno HG, et al. (1997) A mode for photothermal responses of flowering in rice I. Model description and parameterization. Field Crops Res 51:189-200.

33. Vergara BS, Chang TT (1976) The flowering response of the rice plant to photoperiod: A review of the literature. Int Rice Res Inst, Plant photoperiodism $1-66$.

34. Jamieson PD, Martin RJ, Francis GS, Wilson DR (1995) Drought effects on biomass production and radiation-use efficiency in barley. Field Crops Res 43 : $77-86$

35. Jagadish SVK, Murty MVR, Quick WP (2015) Rice responses to rising temperatures-challenges, perspectives and future directions. Plant Cell Environ 38: 1686-1698.

36. Pandey V, Shukla A (2015) Acclimation and tolerance strategies of rice under drought stress. Rice Sci 22: 147-161.

37. O'toole JC, Namuco OS (1983) Role of panicle exsertion in water stress induced sterility. Crop Sci 23:1093-1097.

38. Ekanayake IJ, Steponkus PL, De Datta SK (1990) Sensitivity of pollination to water deficits at anthesis in upland rice. Crop Sci 30: 310-315.

39. Sun H, Zhou S, Fu Z, Chen G, Zou G, et al. (2016) A two-year field measurement of methane and nitrous oxide fluxes from rice paddies under contrasting climate conditions. Scientific reports 6: 28255 .

40. Chirkova T, Yemelyanov $V(2018)$ The study of plant adaptation to oxygen deficiency in Saint Petersburg University. Bio Comm 63: 17-31.

41. Rahman M, Grover A, Peacock WJ, Dennis ES, Ellis MH (2001) Effects of manipulation of pyruvate decarboxylase and alcohol dehydrogenase levels on the submergence tolerance of rice. Funct Plant Biol 28: 1231-1241.

42. Sultana T, Ahamed KU, Naher N, Islam MS, Jaman MS (2017) Growth and yield response of some rice genotype under different duration of complete submergence. IJABE 15: 1-11.

43. Buti M, Pasquariello M, Ronga D, Milc JA, Pecchioni N, et al. (2018) Transcriptome profiling of short-term response to chilling stress in tolerant and sensitive Oryza sativa ssp. Japonica seedlings. Funct Integr genomics 1-18.

44. Cen W, Liu J, Lu S, Jia P, Yu K, et al. (2018) Comparative proteomic analysis of QTL CTS-12 derived from wild rice (Oryza rufipogon Griff.), in the regulation of cold acclimation and de-acclimation of rice (Oryza sativa L.) in response to severe chilling stress. BMC plant biol 18: 163.

45. Food and Agricultural Organization (FAO) (2014) "Core Production Data" FAOSTAT database.

46. Tack J, Singh RK, Nalley LL, Viraktamath BC, Krishnamurthy SL, et al. (2015) High vapor pressure deficit drives salt $\square$ stress $\square$ induced rice yield losses in India. Glob chang biol 21:1668-1678.

47. Apse MP, Sottosanto JB, Blumwald E (2003) Vacuolar cation/H+ exchange, ion homeostasis, and leaf development are altered in a T $\square$ DNA insertional mutan of AtNHX1, the Arabidopsis vacuolar $\mathrm{Na}+/ \mathrm{H}+$ antiporter. Plant J 36: 229-239.

48. Kochian LV, Hoekenga OA, Pineros MA (2004) How do crop plants tolerate acid soils? Mechanisms of aluminum tolerance and phosphorous efficiency. Ann Rev of Plant Biol 55:459-493.

49. Yang LH, Rudolf VHW (2010) Phenology, ontogeny and the effects of climate change on the timing of species interactions. Ecol lett 13: 1-10.

50. Xu J, Lan H, Fang H, Huang X, Zhang H (2015) Quantitative proteomic analysis of the rice (Oryza sativa L.) salt response. PLoS One 10: e0120978.

51. Wang X, Shan X, Wu Y, Su S, Li S (2016) iTRAQ-based quantitative proteomic analysis reveals new metabolic pathways responding to chilling stress in maize seedlings. J Proteomics 146: 14-24.

52. Mu Q, Zhang W, Zhang Y, Yan H, Liu K (2017) iTRAQ-Based Quantitative Proteomics Analysis on Rice Anther Responding to High Temperature. Int $J$ Mol Sci 18.

53. Shahzad K, Loor J (2012) Application of top-down and bottom-up systems approaches in ruminant physiology and metabolism. Curr Genomics 13: 379394.

54. Ouk M, Basnayake J, Tsubo M, Fukai S, Fischer KS, et al. (2006) Use of drought response index for identification of drought tolerant genotypes in rainfed lowland rice. Field Crops Res 99: 48-58.

55. Dar MH, Singh S, Zaidi NW, Shukla S (2012) Sahbhagi Dhan: Science's answer to drought problems. STRASA News 5: 1-13

56. Bernier J, Serraj R, Kumar A, Venuprasad R, Impa S, et al. (2009) The largeeffect drought-resistance QTL qtl12. 1 increases water uptake in upland rice. Field Crops Res 110: 139-146.

57. Markam NK (2013) Screening of rice genotypes against high temperature stress. Doctoral dissertation, Indira Gandhi Krishi Vishwavidyalaya 140.

58. Agrawal L, Gupta S, Mishra SK, Pandey G, Kumar S, et al. (2016) Elucidation of complex nature of PEG induced drought-stress response in rice root using comparative proteomics approach. Front plant sci 7: 1466.

59. Tekharuddaula KM, Newaz MA, Salam MA, Ahmed HU, Mahbub MA, et al. (2011) Rapid and high-precision marker assisted backcrossing to introgress the SUB1 QTL into BR11, the rainfed lowland rice mega variety of Bangladesh. Euphytica 178: 83-97.

60. Sripongpangkul K, Posa GB, Senadhira DW, Brar D, Huang N, et al. (2000) Genes/QTLs affecting flood tolerance in rice. Theor Appl Genet 101: 1074 1081

61. Toojinda T, Siangliw M, Tragoonrung S, Vanavichit A (2003) Molecular genetics of submergence tolerance in rice: QTL analysis of key traits. Ann Bot 91: 243253.

62. Fukao T, Xu K, Ronald PC, Bailey-Serres J (2006) A variable cluster of ethylene responsive-like factors regulates metabolic and developmental acclimation responses to submergence in rice. Plant Cell 18: 2021-2034.

63. Xu K, Xu X, Fukao T, Canlas P, Maghirang-Rodriguez R, et al. (2006) Sub1A is an ethylene-response-factor-like gene that confers submergence tolerance to rice. Nature 442: 705-708.

64. Minami A, Yano K, Gamuyao R, Nagai K, Kuroha T, et al. (2018) Time-course transcriptomics analysis reveals key responses of submerged deepwater rice to flooding. Plant physiol 176: 3081-3102.

65. Vijayan J, Senapati S, Ray S, Chakraborty K, Molla KA et al. (2018) Transcriptomic and physiological studies identify cues for germination stage oxygen deficiency tolerance in rice. Environ Exp Bot 147: 234-248.

66. Singh VK, Singh BD, Kumar A, Maurya S, Krishnan SG, et al. (2018) MarkerAssisted Introgression of Saltol QTL Enhances Seedling Stage Salt Tolerance in the Rice Variety "Pusa Basmati 1". Int J Genomics 18: 1-12. 
67. Mackill DJ, Ismail AM, Pamplona AM, Sanchez DL, Carandang JJ, et al. (2010) Stress tolerant rice varieties for adaptation to a changing climate. Crop Environ Bioinformatics 7: 250-259.

68. Moon S, Chandran AK, Gho YS, Park SA, Kim SR, et al. (2018) Integrated omics analysis of root-preferred genes across diverse rice varieties including Japonica and indica cultivars. J plant physiol 220: 11-23.

69. Shahzad R, Harlina PW, Ayaad M, Ewas M, Nishawy E, et al. (2018) Dynamic roles of microRNAs in nutrient acquisition and plant adaptation under nutrient stress: A review. Plant Omics 11: 58-79.

70. Ma Y, Dai X, Xu Y, Luo W, Zheng X, et al. (2015) COLD1 confers chilling tolerance in rice. Cell 160: 1209-1221.

71. Jin YM, Piao R, Yan YF, Chen M, Wang L, et al. (2018) Overexpression of a new zinc finger protein transcription factor OsCTZFP8 improves cold tolerance in rice. Int J Genomics 18: 1-13.

72. Liang Y, Meng L, Lin X, Cui Y, Pang Y, et al. (2018) QTL and QTL networks for cold tolerance at the reproductive stage detected using selective introgression in rice. PloS one 13: e0200846.

73. Mahender A, Anandan A, Pradhan SK, Singh ON (2018) Traits-related QTLs and genes and their potential applications in rice improvement under low phosphorus condition. Arch Agron Soil Sci 64: 449-464

74. Nguyen BD, Brar DS, Bui BC, Nguyen TV, Pham LN, et al. (2003) Identification and mapping of the QTL for aluminum tolerance introgressed from the new source, Oryza rufipogon Griff., into indica rice (Oryza sativa L.). Theor Appl Genet 106: 583-593.

75. Wissuwa M, Wegner J, Yano M (2002) Substitution mapping of Pup1: A major QTL increasing phosphorus uptake of rice from a phosphorus deficient soil. Theor Appl Genet 105: 890-897.

76. Tanaka J, Chin JH, Dramé KN, Dalid C, Heuer S, et al. (2014) A novel allele of the P-starvation tolerance gene OSPSTOL 1 from African rice (Oryza glaberrima Steud) and its distribution in the genus Oryza. Theor Appl genet 127: 13871398.

77. Gho YS, An G, Park HM, Jung, KH (2018) A systemic view of phosphate starvation-responsive genes in rice roots to enhance phosphate use efficiency in rice. Plant Biotechnol Reports 12: 249-264.

78. Liu H, Soomro A, Zhu Y, Qiu X, Chen K, et al. (2016) QTL underlying iron and zinc toxicity tolerances at seedling stage revealed by two sets of reciprocal introgression populations of rice (Oryza Sativa L.). Crop J 4: 280-289.

79. Neeraja CN, Maghirang-Rodriguez R, Pamplona A, Heuer S, Collard BCY (2007) A marker-assisted backcross approach for developing submergencetolerant rice cultivars. Theor Appl Genet 115: 767-776.

80. Septiningsih EM, Pamplona AM, Sanchez DL, Maghirang- Rodriguez R, Neeraja CN, et al. (2009) Development of submergence-tolerant rice cultivars: The Sub1 gene and beyond. Ann Bot 103: 151-60.

81. Kumar A, Bernier J, Verulkar S, Lafitte HR, Atlin GN (2008) Breeding for drough tolerance: Direct selection for yield, response to selection and use of droughttolerant donors in upland and lowland-adapted populations. Field Crops Res 107: 221-231.

82. Venuprasad R, Dalid CO, Del Valle M, Zhao D, Espiritu M, et al. (2009) Identification and characterization of large-effect quantitative trait loci for grain yield under lowland drought stress in rice using bulk-segregant analysis. Theor Appl Genet 120: 177-190.

83. Dar MH, Singh S, Singh US, Zaidi NW, Ismail AM (2014) Stress tolerant rice varieties-making headway in India. SATSA Mukhaptra Annual Technical Issue 18: 1-4.

84. Rao PS, Mishra B, Gupta SR, Rathore A (2008) Reproductive stage tolerance to salinity and alkalinity stresses in rice genotypes. Plant Breeding 7: 256-261.

85. Islam MT, Sharma PC, Gautam RK, Singh D, Singh S, et al. (2011) Salt tolerance in parental lines of rice hybrids through physiological attributes molecular markers. Int J Expt Agric 2: 1-7.

86. Babu NN, Krishnan SG, Vinod KK, Krishnamurthy SL, Singh VK, et al. (2017) Marker aided incorporation of Saltol, a major QTL associated with seedling stage salt tolerance, into Oryza sativa 'Pusa Basmati 1121'. Front Plant Sci 8: 41 .

87. Mickelbart MV, Hasegawa PM, Bailey-Serres J (2015) Genetic mechanisms of abiotic stress tolerance that translate to crop yield stability. Nat Rev Genet 16: $237-251$. 